\title{
Immediate tooth replantation: root canal filling for delayed initiation of endodontic treatment
}

\section{Daniela Atili BRANDINI(a) Marina Fuzette AMARAL(a) Caio Vinícius Lourenço DEBORTOLI(a) Sônia Regina PANZARINI(a)}

(a) Universidade Estadual Paulista - Unesp, School of Dentistry, Surgery and Integrated Clinics, Araçatuba, SP, Brazil.

Declaration of Interests: The authors certify that they have no commercial or associative interest that represents a conflict of interest in connection with the manuscript.

Corresponding Author:

Sônia Regina Panzarini

E-mail: panzarin@foa.unesp.br

Submitted: Aug 16, 2017

Accepted for publication: Nov 29, 2017

Last revision: December 18, 2017

\begin{abstract}
The aim of this study is to evaluate the action of paramonochlorophenol associated with Furacin followed by calcium hydroxide $(\mathrm{CH})$ dressing in the control of inflammatory root resorption in cases of immediate tooth replantation with delayed endodontic treatment. A total of 28 incisors of 3 male dogs were extracted and replanted after 15 minutes, and randomly divided into 3 groups: Group I $(n=8)$ - endodontic treatment was performed before the extraction and replantation; Group II $(n=10)$ - endodontic treatment was performed 30 days after replantation and the root canal was filled with $\mathrm{CH}$ dressing; Group III $(\mathrm{n}=10)$ - endodontic treatment was performed 30 days after replantation and root canals received temporary medication of paramonochlorophenol-Furacin followed by $\mathrm{CH}$ dressing. The animals were euthanized 90 days after replantation. The histomorphological events analyzed at the epithelial reattachment site were the intensity and extent of acute and chronic inflammatory processes, periodontal ligament (PDL) organization, the intensity and extent of acute and chronic inflammatory processes in the PDL space, root resorption, bone tissue, and ankylosis. Data were submitted to the Wilcoxon Signed Ranks Test for group comparison $(\alpha=5 \%)$. In Groups I, II and III the periodontal ligament was regenerated and most of the resorption areas were repaired by newly formed cementum. The depth and extent of root resorption were significantly higher in Group II than in Group III. The use of paramonochlorophenol-furacin followed by $\mathrm{CH}$ dressing was more effective in controlling inflammatory root resorption after immediate tooth replantation.
\end{abstract}

Keywords: Tooth Avulsion; Tooth Replantation; Root Canal Preparation; Calcium Hydroxide.

\section{Introduction}

Tooth avulsion is a severe trauma for which the treatment of choice is tooth replantation. ${ }^{1,2}$ According to the International Association for Dental Traumatology protocol, the endodontic treatment of replanted teeth with complete rhizogenesis should be done within 7 to 14 days. However, depending on the clinical situation, a delayed endodontic treatment is recommended; for instance, in cases with established inflammatory resorption. ${ }^{2}$ 
External root resorption is frequent if there is periodontal ligament inflammation, especially after replantation. Controlling contamination is essential, since its persistence could maintain the inflammation and provide conditions for sustained resorption. ${ }^{3}$

The most common infection pathway is through the root canal after pulp necrosis. Therefore, the treatment or prevention of inflammatory resorption requires endodontic treatment. ${ }^{1,4,5}$

The medication most commonly employed for endodontic treatment after tool replantation is calcium hydroxide $(\mathrm{CH}){ }^{6}{ }^{6}$ which has excellent biological properties. However, $\mathrm{CH}$ action inside the dentinal tubules and ramifications of the root canal is prolonged and it has little effectiveness against microorganisms, such as Enterococci faecali, that resist to high $\mathrm{pH}$ values and are the main cause of endodontic failure. ${ }^{7,8}$

An ideal initial dressing should act quickly and effectively on the septic content of the main root canal and its ramifications, which in combination with biomechanical preparation would significantly reduce the local microbiota. Therefore, the application of $\mathrm{CH}$ is the best way to remove residual bacteria and their toxins. ${ }^{10}$

The drugs used in the first treatment session should have low toxicity, disperse easily in the dentin and have proven effectiveness, like paramonochlorophenol associated with Furacin. ${ }^{10,11,12}$

Paramonochlorophenol is a germicide with a high antibacterial action used as a delay dressing; however, it is also highly cytotoxic. In order to reduce tissue irritation, some substances, such as camphor ${ }^{13}$ and Furacin ${ }^{11}$, have been used in association with this drug. Although paramonochlorophenol and camphor is the most used drug combination in necropulpectomies, the option for using paramonochlorophenol with Furacin is based on the following characteristics: it has a high antibacterial action and a low cytotoxic effect, is effective against practically all bacteria found in root canals ${ }^{11}$ is water soluble and spreads more easily into the dentin. ${ }^{14,15,16}$ These advantages could explain the better results reported by Holland et al. ${ }^{15}$, who conducted a study to compare paramonochlorophenol with Furacin and camphorated paramonochlorophenol as intracanal dressing in the treatment of chronic periapical lesions in dog teeth.

\section{Objective}

Since there are no studies in the literature that have employed the association of paramonochlorophenol with Furacin followed by $\mathrm{CH}$ dressing in tooth replantation, the aim of this study was to evaluate the action of such treatment protocol in the control of inflammatory root resorption in teeth endodontically treated 30 days after immediate tooth replantation.

\section{Material and Methods}

The research protocol was approved by the Committee of Animal Care and Research Use (protocol 2010-004113), and all guidelines regarding the care of research animals were strictly observed.

Three young adult male dogs of similar size with an average weight of $30 \mathrm{~kg}$ raised in a vivarium registered with the Brazilian Society of Science in Laboratory Animals were used for the study (SBCAL/COBEA). A total of 28 upper central and middle incisors, and lower central, middle and lateral incisors of the animals were extracted, following the protocol below.

The animals were given the pre-anesthetic agent Acepromazine 1\% (Vetnil Ind. e Com. de Produtos Veterinários Ltda, Louveira, Brazil) and ketamine 50 mg/mL (Ceva Saúde Animal Ltda, Paulínia, Brazil) via intramuscular injection for sedation. Next, general anesthesia was performed by intravenous administration of Zoletil $100 \mathrm{mg} / \mathrm{mL}$ solution (Virbac do Brazil, São Paulo, Brazil). Intravenous access was maintained by means of a scalpel $n^{\circ} 21$ (Butterfly, Abbott Ireland, Sligo, Ireland) in order to hydrate the animals with 5\% dextrose solution (Laboratório J. P., Indústria Farmacêutica S. A., Ribeirão Preto, Brazil).

The teeth were divided into 3 groups according to the proposed treatment:

Group I $(n=08)$ : endodontic treatment in one session using Sealapex (Sybron Kerr Indústria e Comércio Ltda, Guarulhos, Brazil) as sealer, tooth extraction and replantation. Euthanasia was performed 90 days after replantation.

Group II $(n=10)$ : tooth extraction, replantation and endodontic treatment 30 days after replantation using $\mathrm{CH}$ dressing. A paste containing $\mathrm{CH}$, saline and iodoform was prepared and applied into the root canal using a Lentulo spiral (Dentsply-Maillefer 
Indústria e Comércio Ltda., Petrópolis, Brazil). Next, the teeth were sealed with gutta-percha and chemically activated glass ionomer cement (Vidrion R, SS White, Rio de Janeiro, Brazil). The dressing was changed after 7 and 60 days, and remained in place until the end of the experiment (90 days).

Group III $(n=10)$ : tooth extraction, replantation and endodontic treatment 30 days after replantation using paramonochlorophenol + Furacin (Biodinâmica Química Farmacêutica Ltda., Abatiá, Brazil) at $5 \mathrm{~g} / 28 \mathrm{~mL}$, applied with an absorbent paper cone previously adapted to the root canal; teeth were sealed as described above. After 7 days the crown seal was removed, the canals were irrigated with sodium hypochlorite $2.5 \%$, dried with absorbent paper cones, filled with a paste of calcium hydroxide, saline and iodoform, and then sealed again. This procedure was repeated on day 60 , after which the dressing remained in place until the end of the experiment (90 days).

Table 1 illustrates the performed treatment sequence.

The extraction procedure was performed through an intrasulcular incision with a \#15 scalpel blade, straight lever luxation and seizure with a pediatric forceps (Edlo, Indústria Gaúcha de Instrumentos Cirúrgicos Ltda, Canoas, Brazil).

The teeth were kept dry at room temperature for a period of 15 minutes. The alveoli were irrigated with saline, after which the teeth were replanted and splinted with 0.7 steel wire (Morelli, Sorocaba, Brazil) and composite resin (TPH Spectrum, Dentsply, Petrópolis, RJ, Brazil), which remained in place for 15 days.
All animals received an intramuscular injection of penicillin (Eurofarma Laboratories Ltda., Belo Campo, Brazil) at a dose of $250 \mathrm{mg}$, an intramuscular injection of Dipyrone Sodium $500 \mathrm{mg} / \mathrm{mL}$ (Laboratório Ibasa Ltda, Porto Alegre, Brazil) and anti-inflammatory Keptoprofeno 10\% (Laboratórios Vencofarma do Brazil LTDA, Londrina, Brazil) every 12 hours orally for 3 days.

The root canal treatment followed the same protocol for all teeth. Following rubber dam isolation, the root cavity was opened, pulpectomy was performed, the working length was determined, and the root canals were instrumented by a crown-down technique until reaching the apical cemental barrier. Next, the apical cemental barrier was penetrated with a \#15 K-file (Maillefer Instruments SA, Ballaigues, Switzerland), and the cemental canal was widened up with a \#25 K-file. Throughout the procedure, the root canals were irrigated with sodium hypochlorite $2.5 \%$. The prepared canals were then dried and immediately obturated with gutta-percha cones and Sealapex (Group I), and divided in accordance with the intracanal medication (Group II and III).

The animals (Group I, II, III) were euthanized by anesthetic overdose 90 days after the treatment. Subsequently, the anatomic pieces containing the teeth were removed, fixed in buffered neutral 10\% formalin, decalcified in 17\% EDTA solution, and embedded in paraffin. The blocks were serially sectioned into $6-\mu \mathrm{m}$ thick longitudinal sections that were stained with hematoxylin and eosin, and then examined under light microscopy by a skilled observer blind to the treatment groups.

Table 1. Study treatment sequence.

\begin{tabular}{|c|c|c|c|c|c|c|c|}
\hline \multirow{3}{*}{ Groups } & \multirow{3}{*}{$N$} & \multicolumn{6}{|c|}{ Performed treatment } \\
\hline & & \multirow{2}{*}{$1^{\text {st }}$ session } & $2^{\text {nd }}$ session & $3^{\text {rd }}$ session & $4^{\text {th }}$ session & $5^{\text {th }}$ session & $6^{\text {th }}$ session \\
\hline & & & 15 days & 30 days & 37 days & 60 days & 90 days \\
\hline Group I & 8 & $\begin{array}{l}\text { Endodontic treatment before } \\
\text { extraction and replanted }\end{array}$ & Splint removal & & & & euthanasia \\
\hline Group II & 10 & extraction and replanted & Splint removal & $\mathrm{CH}$ dressing & $\begin{array}{l}\mathrm{CH} \text { dressing } \\
\text { change }\end{array}$ & $\begin{array}{l}\mathrm{CH} \text { dressing } \\
\text { change }\end{array}$ & euthanasia \\
\hline Group III & 10 & extraction and replanted & Splint removal & $\begin{array}{l}\text { paramonochlorophenol } \\
\quad+\text { Furacin dressing }\end{array}$ & $\mathrm{CH}$ dressing & $\begin{array}{l}\mathrm{CH} \text { dressing } \\
\text { change }\end{array}$ & euthanasia \\
\hline
\end{tabular}

$\mathrm{CH}$ : calcium hydroxide. 
The histomorphological parameters used in the present study are based on the criteria described by Panzarini et al. ${ }^{17}$ The specimens were examined and scores from 1 to 4 were assigned to each parameter, with 1 indicating the best result and 4 the worst. The histological events analyzed at the epithelial reattachment site were the intensity and extent of acute and chronic inflammatory processes, periodontal ligament (PDL) organization, intensity and extent of acute and chronic inflammatory processes in the PDL space, root resorption (active or inactive, extent, depth and repair), bone tissue, and ankylosis (Table2, Figure 1).

The data were submitted to the Wilcoxon signed rank test (non-parametric repeated measures analysis) for comparison between groups, at SPSS 20.0, at a significance level of $5 \%$.

\section{Results}

\section{Group I - endodontic treatment before tooth replantation}

The periodontal ligament was reattached to the cementum and alveolar bone, with fibers arranged perpendicularly to the root surface, preserving structures like the epithelial cell rests of Malassez that confirm regeneration. Newly formed cementum was observer in the root resorption areas (Table 3), preserving the periodontal ligament space (Figure 2A). In the apical region near the delta, a subtle acute and chronic inflammatory infiltrate (Table 4) and active bone resorption (Table 5) were noted (Figure 2B).

\section{Group II - CH dressing}

The periodontal ligament was completely preserved. The external root resorption was assigned a score 3 for its extent and depth in $60 \%$ of the cases (Table 4 ), and was mostly repaired by newly formed cementum (Figure 2C). There was a small incidence of ankylosis (Table 5). Acute inflammatory infiltrates near the ramifications were observed (Figure 2D) as well as massive presence of active resorption of bone tissue (Table 5).

\section{Group III - paramonochlorophenol + Furacin followed by $\mathrm{CH}$ dressing}

The periodontal ligament was reattached to the cementum and alveolar bone with fibers arranged perpendicularly to the root surface (Table 2). Epithelial cell rests of Malassez were present (Figure 2E). Fifty percent of the root surfaces had no active resorption (Table 3). Most root resorptions were small in extent and depth (Table 3), and repaired by newly formed cementum (Figure 2F). In the alveolar bone tissue, a level 3 active resorption was noted in $100 \%$ of the cases (Table 5).

Table 2. Distribution of scores and statistical analysis of the histomorphometric events associated with epithelial reattachment (Wilcoxon signed ranks test at 5\% significance level).

\begin{tabular}{|c|c|c|c|}
\hline \multirow[b]{2}{*}{ Group/Events/Scores } & \multicolumn{3}{|c|}{ Epithelial reattachment } \\
\hline & $\begin{array}{l}\text { Endodontic } \\
\text { treatment }\end{array}$ & $\mathrm{CH}$ & $\mathrm{PMCF}+\mathrm{CH}$ \\
\hline \multicolumn{4}{|l|}{ Site } \\
\hline 1 & $08 / 8$ & $10 / 10$ & $10 / 10$ \\
\hline 2 & $0 / 8$ & $0 / 10$ & $0 / 10$ \\
\hline 3 & $0 / 8$ & $0 / 10$ & $0 / 10$ \\
\hline 4 & $0 / 8$ & $0 / 10$ & $0 / 10$ \\
\hline Intergroup comparison & \multicolumn{3}{|c|}{ Unable to statistics - the same scores } \\
\hline \multicolumn{4}{|c|}{ Intensity of the acute inflammatory process } \\
\hline 1 & $06 / 8$ & $08 / 10$ & $02 / 10$ \\
\hline 2 & $2 / 8$ & $2 / 10$ & $08 / 10$ \\
\hline 3 & $0 / 8$ & $0 / 10$ & $0 / 10$ \\
\hline 4 & $0 / 8$ & $0 / 10$ & $0 / 10$ \\
\hline Intergroup comparison & $a$ & a & $a$ \\
\hline \multicolumn{4}{|c|}{ Extent of the acute inflammatory process } \\
\hline 1 & $03 / 8$ & $05 / 10$ & $04 / 10$ \\
\hline 2 & $05 / 8$ & $05 / 10$ & $06 / 10$ \\
\hline 3 & $0 / 8$ & $0 / 10$ & $0 / 10$ \\
\hline 4 & $0 / 8$ & $0 / 10$ & $0 / 10$ \\
\hline Intergroup comparison & a & a & $a$ \\
\hline \multicolumn{4}{|c|}{ Intensity of the chronic inflammatory process } \\
\hline 1 & $06 / 8$ & $09 / 10$ & $06 / 10$ \\
\hline 2 & $02 / 8$ & $01 / 10$ & $04 / 10$ \\
\hline 3 & $0 / 8$ & $0 / 10$ & $0 / 10$ \\
\hline 4 & $0 / 8$ & $0 / 10$ & $0 / 10$ \\
\hline Intergroup comparison & a & a & $a$ \\
\hline \multicolumn{4}{|c|}{ Extent of the chronic inflammatory process } \\
\hline 1 & $01 / 8$ & $01 / 10$ & $02 / 10$ \\
\hline 2 & $07 / 8$ & $09 / 10$ & $08 / 10$ \\
\hline 3 & $0 / 8$ & $0 / 10$ & $0 / 10$ \\
\hline 4 & $0 / 8$ & $0 / 10$ & $0 / 10$ \\
\hline Intergroup comparison & $a$ & $a$ & $a$ \\
\hline
\end{tabular}

$\mathrm{CH}$ : calcium hydroxide; PMCF: 


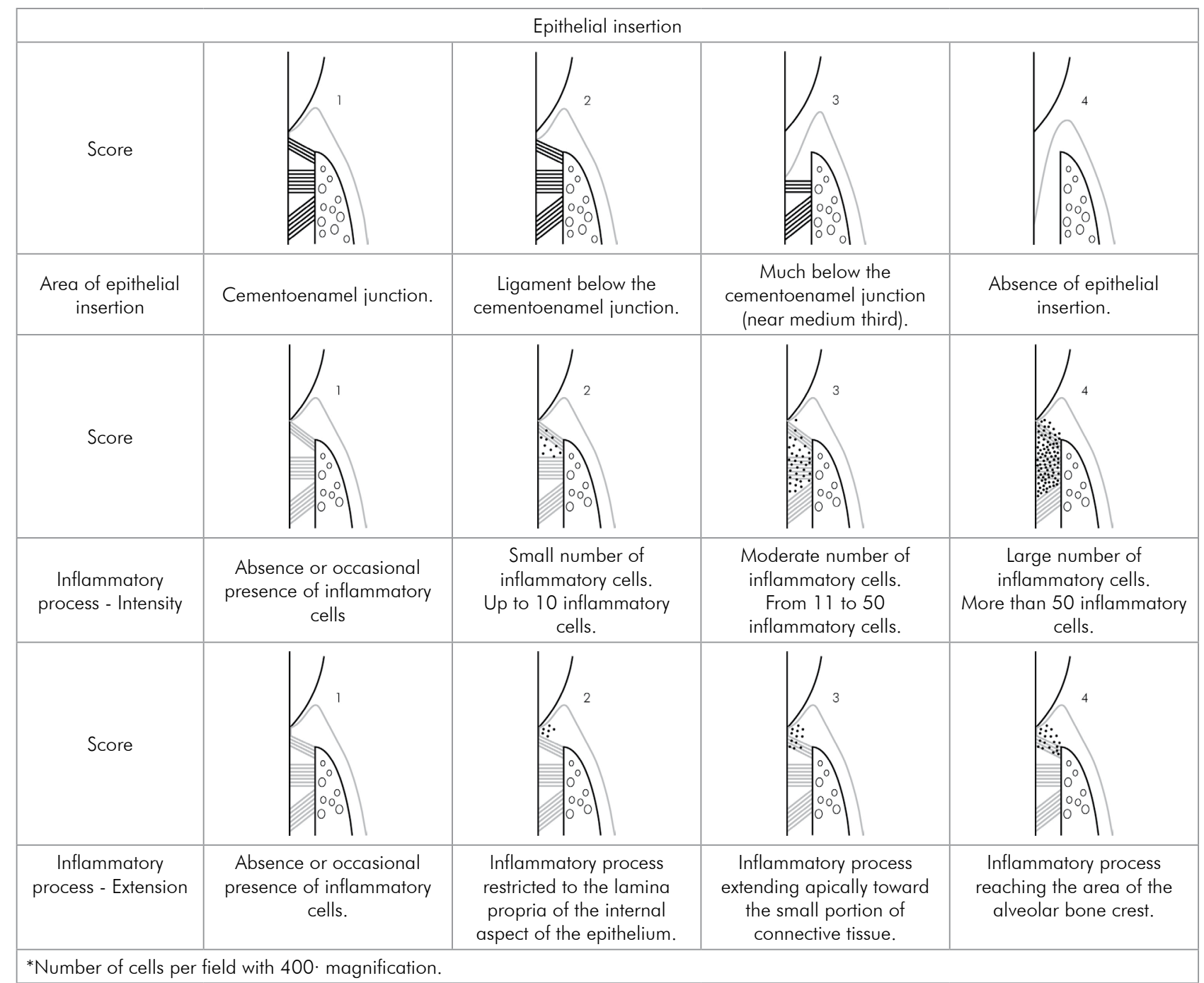

\begin{tabular}{|c|c|c|c|c|}
\hline \multicolumn{5}{|c|}{ Tooth root } \\
\hline \multicolumn{5}{|l|}{ Score } \\
\hline Root Resorption & $\begin{array}{l}\text { Absence of root resorptions } \\
\text { or repaired resorptions. }\end{array}$ & $\begin{array}{l}\text { Areas of inactive resorptions } \\
\text { (absence of clastic cells). }\end{array}$ & $\begin{array}{l}\text { Small areas of active } \\
\text { resorptions. }\end{array}$ & $\begin{array}{c}\text { Extensive areas of active } \\
\text { resorptions. }\end{array}$ \\
\hline $\begin{array}{l}\text { Extesion of root } \\
\text { resorption }\end{array}$ & Absence of resorption. & $\begin{array}{c}\text { Mean extension of } 1-1000 \\
\mu \mathrm{m} .\end{array}$ & $\begin{array}{l}\text { Mean extension of } \\
1001-5000 \mu \mathrm{m} \text {. }\end{array}$ & $\begin{array}{l}\text { Mean extension larger than } \\
5001 \mu \mathrm{m} \text {. }\end{array}$ \\
\hline $\begin{array}{l}\text { Depth of root } \\
\text { resorption }\end{array}$ & Absence of resorption. & SMean depth of $1-100 \mu \mathrm{m}$. & $\begin{array}{l}\text { Mean depth of 101-200 } \\
\mu \mathrm{m} .\end{array}$ & $\begin{array}{l}\text { Mean depth larger than } \\
201 \mu \mathrm{m} .\end{array}$ \\
\hline $\begin{array}{l}\text { Repair of root } \\
\text { resorption areas }\end{array}$ & $\begin{array}{l}\text { Absence of resorption or } \\
\text { deposition of newly formed } \\
\text { cementum all the extension. }\end{array}$ & $\begin{array}{l}\text { Deposition of newly formed } \\
\text { cementun in half or more } \\
\text { the extension. }\end{array}$ & $\begin{array}{l}\text { Deposition of newly formed } \\
\text { cementun in less than half } \\
\text { of the extension. }\end{array}$ & $\begin{array}{l}\text { Absence of deposition of } \\
\text { newly formed cementun. }\end{array}$ \\
\hline
\end{tabular}

Figure 1. Scores used in the quantification of histological events. 


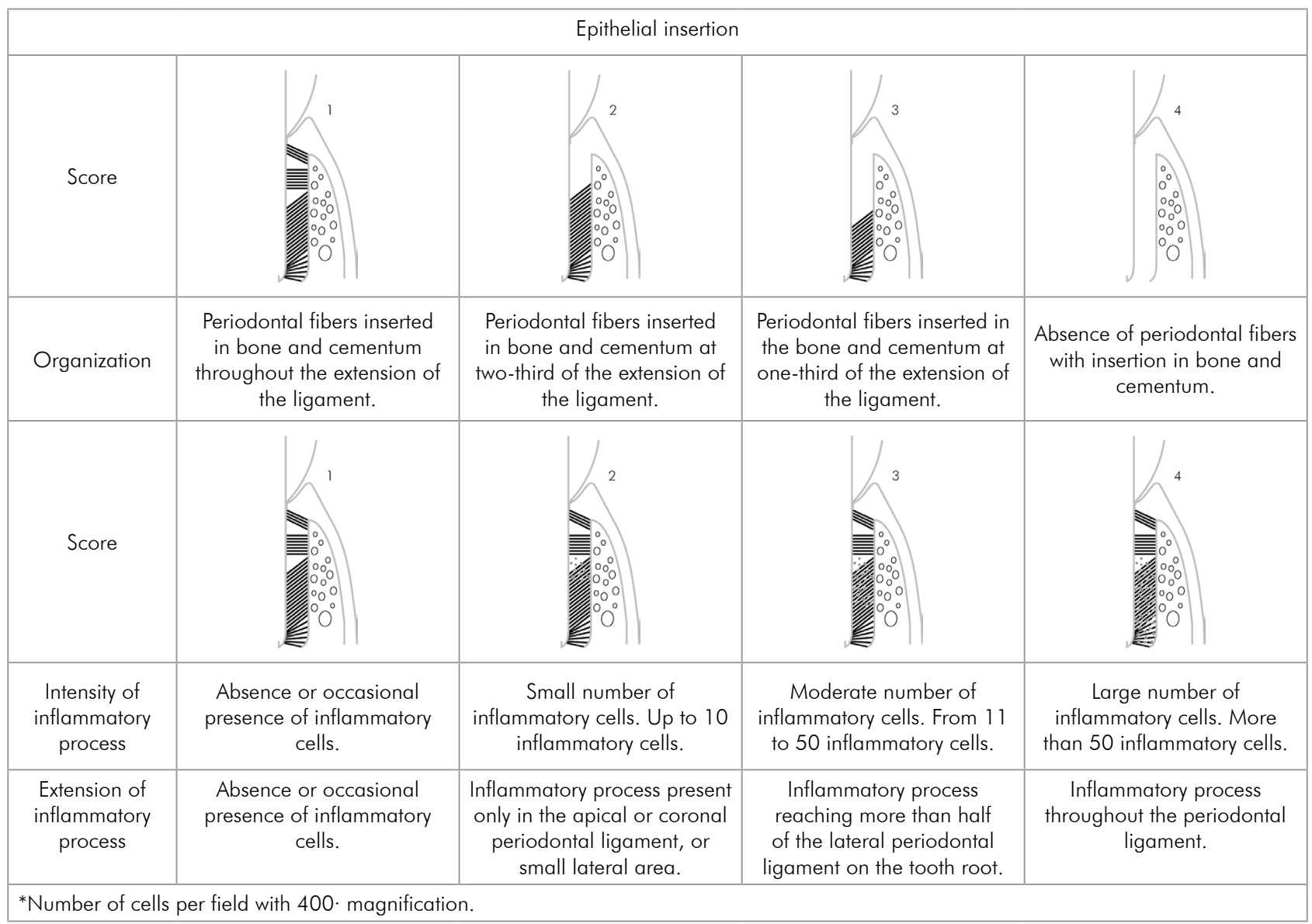

\begin{tabular}{|c|c|c|c|c|}
\hline \multicolumn{5}{|c|}{ Bone tissue } \\
\hline \multicolumn{5}{|l|}{ Score } \\
\hline $\begin{array}{c}\text { Bone } \\
\text { Resorption }\end{array}$ & Absence of resorptions areas. & $\begin{array}{l}\text { Presence of inactive } \\
\text { resorptions areas (absence } \\
\text { of clastic cells). }\end{array}$ & $\begin{array}{c}\text { Presence of small areas of } \\
\text { active resorption. }\end{array}$ & $\begin{array}{c}\text { Presence of extensive areas } \\
\text { of active resorption. }\end{array}$ \\
\hline \multicolumn{5}{|l|}{ Score } \\
\hline Ankylosis & Absence of ankylosis. & Small points of ankylosis. & $\begin{array}{c}\text { One-third of the root with of } \\
\text { ankylosis. }\end{array}$ & $\begin{array}{l}\text { More than one-third of the } \\
\text { root with of ankylosis. }\end{array}$ \\
\hline
\end{tabular}

Figure 1. (Continuation) Scores used in the quantification of histological events. 
Table 3. Distribution of scores and statistical analysis of the histomorphometric events associated with root dentin resorption (Wilcoxon signed ranks test at 5\% significance level).

\begin{tabular}{|c|c|c|c|}
\hline \multirow[b]{2}{*}{ Group/Events/Scores } & \multicolumn{3}{|c|}{ Tooth root } \\
\hline & $\begin{array}{l}\text { Endodontic } \\
\text { treatment }\end{array}$ & $\mathrm{CH}$ & $\mathrm{PMCF}+\mathrm{CH}$ \\
\hline \multicolumn{4}{|c|}{ Areas of active root resorption } \\
\hline 1 & $0 / 8$ & 03/10 & $05 / 10$ \\
\hline 2 & $2 / 8$ & 03/10 & 03/10 \\
\hline 3 & $6 / 8$ & $04 / 10$ & $02 / 10$ \\
\hline 4 & $0 / 8$ & $0 / 10$ & $0 / 10$ \\
\hline Intergroup comparison & a & $a b$ & $b$ \\
\hline \multicolumn{4}{|l|}{ Extent of root resorption } \\
\hline 1 & $0 / 8$ & $0 / 10$ & $01 / 10$ \\
\hline 2 & $3 / 8$ & $4 / 10$ & $09 / 10$ \\
\hline 3 & $5 / 8$ & $6 / 10$ & $0 / 10$ \\
\hline 4 & $0 / 8$ & $0 / 10$ & $0 / 10$ \\
\hline Intergroup comparison & $a$ & $a$ & $b$ \\
\hline \multicolumn{4}{|l|}{ Depth of root resorption } \\
\hline 1 & $0 / 8$ & $0 / 10$ & $01 / 10$ \\
\hline 2 & 04/8 & $04 / 10$ & $08 / 10$ \\
\hline 3 & $04 / 8$ & $06 / 10$ & $01 / 10$ \\
\hline 4 & $0 / 8$ & $0 / 10$ & $0 / 10$ \\
\hline Intergroup comparison & $a b$ & $a$ & $b$ \\
\hline \multicolumn{4}{|c|}{ Repair of root resorption areas } \\
\hline 1 & $0 / 8$ & 03/10 & $06 / 10$ \\
\hline 2 & 07/8 & $07 / 10$ & $04 / 10$ \\
\hline 3 & $01 / 8$ & $0 / 10$ & $0 / 10$ \\
\hline 4 & $0 / 8$ & $0 / 10$ & $0 / 10$ \\
\hline Intergroup comparison & $a$ & $a b$ & $b$ \\
\hline
\end{tabular}

$\mathrm{CH}$ : calcium hydroxide; PMCF:

\section{Discussion}

The maintenance of replanted teeth is directly related to the viability of the periodontal ligament cells and contamination control. ${ }^{1}$

When the replantation is performed after a short extra-alveolar period, as was the case in this study, a complete regeneration of the periodontal ligament can occur, with all structural components (cementoblasts, fibroblasts, and collagen fibers) reinserted in the bone and cementum, and presence of blood vessels and epithelial cell rests of Malassez. ${ }^{1}$

These epithelial cells, along with the cementum, are an important part of the periodontal ligament's defense system against bacteria from the root canal, passing
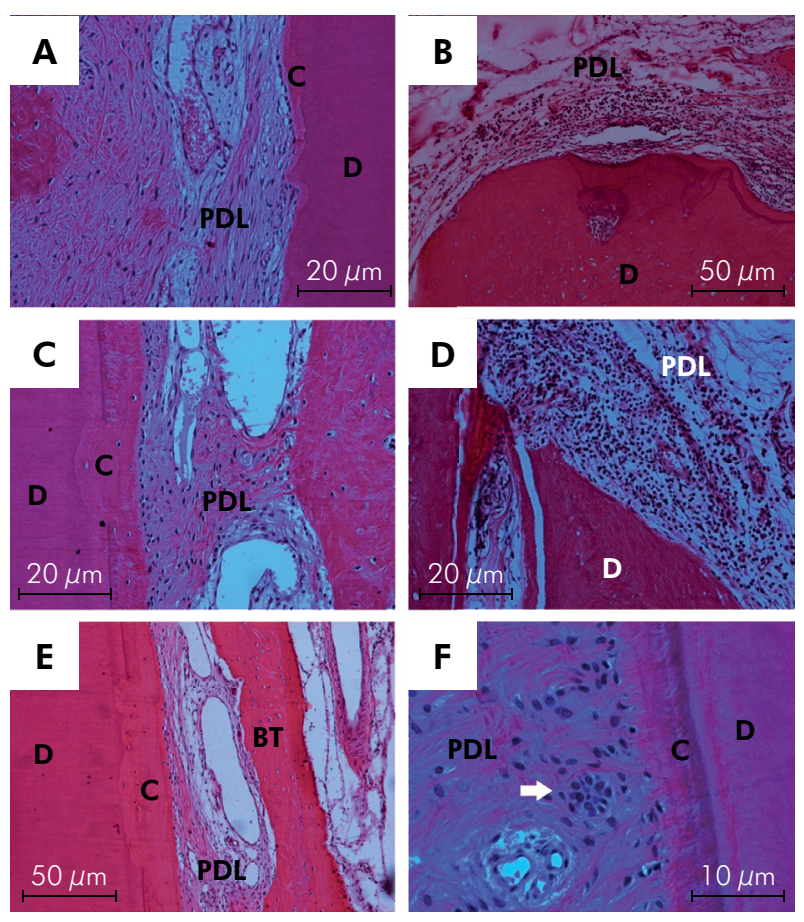

Figure 2. A - Root resorption repaired by newly formed cementum (arrow). B - Presence of acute inflammatory infiltrate in the periodontal ligament near the ramification (arrow). C - Root resorption repaired by newly formed cementum. D - Presence of acute inflammatory infiltrate near a ramification of the main canal (arrow). E - Root resorption repaired by newly formed cementum. F- Presence of epithelial cell rests of Malassez near the root surface (arrow). HE.

through the main canals, lateral ramifications and dentinal tubules. Bacteria promote the proliferation and adhesion of epithelial cells near the contaminated site, with the purpose of forming a barrier against the invaders. ${ }^{3,18-21}$

Another frequent finding of the treated groups was the repair of root resorption by newly formed cementum, which is also directly related to the presence of epithelial cell rests of Malassez. There is evidence that these cells can activate the secretion of proteins that are normally expressed during tooth development and participate in the formation of acellular cementum. ${ }^{22,23}$

After tooth avulsion, endodontic treatment is essential to control contamination in the canal and in the periapical region of the tooth. For intracanal dressing, important aspects must be considered that can directly influence the repair of the periodontal ligament, such as toxicity, effectiveness, action spectrum and mechanism of action. 
Table 4. Distribution of scores and statistical analysis of the histomorphometric events associated with periodontal ligament (Wilcoxon signed ranks test at 5\% significance level).

\begin{tabular}{|c|c|c|c|}
\hline \multirow[b]{2}{*}{ Group/Events/Scores } & \multicolumn{3}{|c|}{ Periodontal ligament } \\
\hline & $\begin{array}{l}\text { Endodontic } \\
\text { treatment }\end{array}$ & $\mathrm{CH}$ & $\mathrm{PMCF}+\mathrm{CH}$ \\
\hline \multicolumn{4}{|l|}{ Organization } \\
\hline 1 & $5 / 8$ & $09 / 10$ & $09 / 10$ \\
\hline 2 & $3 / 8$ & $01 / 10$ & $01 / 10$ \\
\hline 3 & $0 / 8$ & $0 / 10$ & $0 / 10$ \\
\hline 4 & $0 / 8$ & $0 / 10$ & $0 / 10$ \\
\hline Intergroup comparison & a & a & $a$ \\
\hline \multicolumn{4}{|c|}{ Intensity of the acute inflammatory process } \\
\hline 1 & $6 / 8$ & $07 / 10$ & $08 / 10$ \\
\hline 2 & $1 / 8$ & $2 / 10$ & $01 / 10$ \\
\hline 3 & $1 / 8$ & $1 / 10$ & $01 / 10$ \\
\hline 4 & $0 / 8$ & $0 / 10$ & $0 / 10$ \\
\hline Intergroup comparison & a & a & a \\
\hline \multicolumn{4}{|c|}{ Extent of the acute inflammatory process } \\
\hline 1 & $01 / 8$ & $05 / 10$ & $04 / 10$ \\
\hline 2 & $07 / 8$ & $05 / 10$ & $06 / 10$ \\
\hline 3 & $0 / 8$ & $0 / 10$ & $0 / 10$ \\
\hline 4 & $0 / 8$ & $0 / 10$ & $0 / 10$ \\
\hline Intergroup comparison & a & $a$ & a \\
\hline \multicolumn{4}{|c|}{ Intensity of the chronic inflammatory process } \\
\hline 1 & $07 / 8$ & $08 / 10$ & $05 / 10$ \\
\hline 2 & $01 / 8$ & $02 / 10$ & $05 / 10$ \\
\hline 3 & $0 / 8$ & $0 / 10$ & $0 / 10$ \\
\hline 4 & $0 / 8$ & $0 / 10$ & $0 / 10$ \\
\hline Intergroup comparison & a & a & a \\
\hline \multicolumn{4}{|c|}{ Extent of the chronic inflammatory process } \\
\hline 1 & $02 / 8$ & $01 / 10$ & $04 / 10$ \\
\hline 2 & 06/8 & $09 / 10$ & $06 / 10$ \\
\hline 3 & $0 / 8$ & $0 / 10$ & $0 / 10$ \\
\hline 4 & $0 / 8$ & $0 / 10$ & $0 / 10$ \\
\hline Intergroup comparison & a & $a$ & $a$ \\
\hline
\end{tabular}

$\mathrm{CH}$ : calcium hydroxide; PMCF:

Paramonochlorophenol mixed with Furacin promotes a rapid decontamination of the root canal because of its high bactericidal and bacteriostatic proprieties, and low toxicity. ${ }^{11,14}$ This drug acts by contact and spreads easily in the dentinal tubules and ramifications of the main canal, ${ }_{1}^{12}$ which may explain the lesser extent and depth of root resorptions, as well as the absence of acute inflammatory infiltrate near the ramifications.
Table 5. Distribution of scores and statistical analysis of the histomorphometric events associated with bone tissue (Wilcoxon Signed Ranks Test at 5\% significance level).

\begin{tabular}{|c|c|c|c|}
\hline \multirow[b]{2}{*}{ Group/Events/Scores } & \multicolumn{3}{|c|}{ Bone tissue } \\
\hline & $\begin{array}{l}\text { Endodontic } \\
\text { treatment }\end{array}$ & $\mathrm{CH}$ & $\mathrm{PMCF}+\mathrm{CH}$ \\
\hline \multicolumn{4}{|c|}{ Areas of active bone resorption } \\
\hline 1 & $0 / 8$ & $0 / 10$ & $0 / 10$ \\
\hline 2 & $0 / 8$ & $0 / 10$ & $0 / 10$ \\
\hline 3 & $8 / 8$ & $10 / 10$ & $10 / 10$ \\
\hline 4 & $0 / 8$ & $0 / 10$ & $0 / 10$ \\
\hline Intergroup comparison & \multicolumn{3}{|c|}{ Unable to statistics - the same scores } \\
\hline \multicolumn{4}{|l|}{ Ankylosis } \\
\hline 1 & $7 / 8$ & $9 / 10$ & $8 / 10$ \\
\hline 2 & $1 / 8$ & $1 / 10$ & $2 / 10$ \\
\hline 3 & $0 / 8$ & $0 / 10$ & $0 / 10$ \\
\hline 4 & $0 / 8$ & $0 / 10$ & $0 / 10$ \\
\hline Intergroup comparison & $a$ & $a$ & $a$ \\
\hline
\end{tabular}

The rapid decontamination favors the repair process of tooth replantation, because inflammatory resorption usually begins within 15 days after replantation, and the main etiological factor is the contamination of the root canal, its ramifications and dentinal tubules. ${ }^{4}$ Furthermore, the deep action of $\mathrm{CH}$ requires a long time for the treatment of inflammatory resorption. ${ }^{5}$

In group II, which received only $\mathrm{CH}$ as dressing, a presence of acute inflammatory infiltrate was observed near the ramifications, including increased depth and extent of root resorptions compared to group III, probably due to inefficiency or a longer delay in decontamination.

The time until endodontic treatment following replantation is an important factor, ${ }^{24,25}$ because as time passes, the contamination penetrates deeper into the ramifications and dentinal tubules, promoting inflammatory processes in the periodontal ligament and creating conditions for inflammatory root resorption. ${ }^{5}$ This fact was demonstrated here by initiating endodontic treatment 30 days post-replantation.

The advantage of using paramonochlorophenolfuracin dressing followed by $\mathrm{CH}$ to treat inflammatory resorption is the complementary action of the combination, which contributes to an earlier root canal filling.

Paramonochlorofenol with furacin is a medicament that acts by contact, ${ }^{14}$ has a great capacity to diffuse in the dentin and a strong antimicrobial action..$^{12}$ Due to these proprieties, which have been confirmed through 
studies using dog teeth with periapical lesions ${ }^{26}$ the medication is indicated by Holand et al. ${ }^{26}$ as a delayed dressing for necropulpectomy, remaining in place for a short period of 3 to 7 days. The $\mathrm{CH}$ then acts on the residual bacteria and their toxins, which are able to interrupt the resorption process. ${ }^{27}$

The repair process after immediate tooth replantation is more efficient concerning extent and depth of resorptions, compared to delayed tooth replantation. This indicates the important role of a viable periodontal ligament in the preservation of teeth, even if affected by pulp necrosis. ${ }^{28}$

\section{References}

1. Andreasen JO, Andreasen FM, Andersson L. Textbook and color atlas of traumatic injuries to the teeth. 4th ed. Oxford: Blackwell; 2007.

2. Andersson L, Andreasen JO, Day P, Heithersay G, Trope M, Diangelis AJ et al.. International Association of Dental Traumatology guidelines for the management of traumatic dental injuries: 2. Avulsion of permanent teeth. Dent Traumatol. 2012 Apr;28(2):88-96. https://doi.org/10.1111/j.1600-9657.2012.01125.x

3. Consolaro A. Dental resorption in clinical specialties. 2nd ed. Maringa: Dental Press; 2005. p. 123-52.

4. Andreasen JO. Relationship between surface and inflammatory resorption and changes in the pulp after replantation of permanent incisors in monkeys. J Endod. $1981 \mathrm{Jul} ; 7(7): 294-301$. https://doi.org/10.1016/S0099-2399(81)80095-7

5. Trope M, Moshonov J, Nissan R, Buxt P, Yesilsoy C. Short vs. long-term calcium hydroxide treatment of established inflammatory root resorption in replanted dog teeth. Endod Dent Traumatol. 1995 Jun;11(3):124-8. https://doi.org/10.1111/j.1600-9657.1995.tb00473.x

6. Panzarini SR, Trevisan CL, Brandini DA, Poi WR, Sonoda CK, Luvizuto ER et al. Intracanal dressing and root canal filling materials in tooth replantation: a literature review. Dent Traumatol. 2012 Feb;28(1):42-8. https://doi.org/10.1111/j.1600-9657.2011.01023.x

7. Orstavik D, Haapasalo M. Disinfection by endodontic irrigants and dressings of experimentally infected dentinal tubules. Endod Dent Traumatol. 1990 Aug;6(4):142-9. https://doi.org/10.1111/j.1600-9657.1990.tb00409.x

8. Safavi KE, Spangberg LS, Langeland K. Root canal dentinal tubule disinfection. J Endod. 1990 May;16(5):207-10. https://doi.org/10.1016/S0099-2399(06)81670-5 PMID:2074411

\section{Conclusion}

The use of paramonochlorophenol-furacin followed by $\mathrm{CH}$ dressing was more effective than $\mathrm{CH}$ dressing alone regarding the control of inflammatory root resorption after immediate tooth replantation.

\section{Acknowledgements}

This work was supported by Brazil's National Counsel for Technological and Scientific Development - CNPq (process n³03175/2010-9).
9. Farac RV, Pizzolitto AC, Tanomaru JM, Morgental RD, Lima RK, Bonetti-Filho I. Ex-vivo effect of intracanal medications based on ozone and calcium hydroxide in root canals contaminated with Enterococcus faecalis. Braz Dent J. 2013;24(2):103-6. https://doi.org/10.1590/0103-6440201301992

10. Estrela C, Holland R. Calcium hydroxide: study based on scientific evidences. J Appl Oral Sci. 2003 Dec;11(4):269-82. https://doi.org/10.1590/S1678-77572003000400002

11. Zerlotti Filho E. Contribution therapy of root canal [Thesis]. Campinas: Pontifícia Universidade Católica; 1959.

12. Biral RR. Analysis of antimicrobial action of medication used in dressings topics intracanal [Thesis]. Piracicaba: Universidade de Campinas; 1978.

13. Sommer RF, Ostrander FD, Crowley MC. Clinical endodontics. 3rd ed. Philadelphia: W. B. Saunders; 1966.

14. Souza V, Holland R, Nery MJ, Mello W. [Drug use within the root canal: topical action and distance of some drugs]. Ars Curandi Odontol. 1978 Sep;5(6):4-15. Portuguese.

15. Holland R. Emprego tópico de medicamento no interior dos canais radiculares. Odontomaster-Endod. 1994;1 (2):23-5.

16. Panzarini SR, Souza V, Holland R, Dezan Júnior E. Root canal treatment of teeth with chronic periapical lesion: influence of different kinds of dressings and root canal fillings. Rev Odontol UNESP. 1998 Jul;27(2):509-26.

17. Panzarini SR, Holland R, Souza V, Poi WR, Sonoda CK, Pedrini D. Mineral trioxide aggregate as a root canal filling material in reimplanted teeth. Microscopic analysis in monkeys. Dent Traumatol. 2007 Oct;23(5):265-72. https://doi.org/10.1111/j.1600-9657.2006.00456.x

18. Andreasen JO. External root resorption: its implication in dental traumatology, paedodontics, periodontics, orthodontics and endodontics. Int Endod J. 1985 Apr;18(2):109-18. https://doi.org/10.1111/j.1365-2591.1985.tb00427.x 
19. Lindskog S, Blomlöf L, Hammarström L. Evidence for a role of odontogenic epithelium in maintaining the periodontal space. J Clin Periodontol. 1988 Jul;15(6):371-3. https://doi.org/10.1111/j.1600-051X.1988.tb01014.x

20. Becktor KB, Nolting D, Becktor JP, Kiaer I. Immunohistochemical localization of epithelial rests of Malassez in human periodontal membrane. Eur J Orthod. 2007 Aug;29(4):350-3. https://doi.org/10.1093/ejo/cjm023

21. Keinan D, Cohen RE. The significance of epithelial rests of Malassez in the periodontal ligament. J Endod. 2013 May;39(5):582-7. https://doi.org/10.1016/j.joen.2013.01.004 72

22. Hasegawa N, Kawaguchi H, Ogawa T, Uchida T, Kurihara $\mathrm{H}$. Immunohistochemical characteristics of epithelial cell rests of Malassez during cementum repair. J Periodontal Res. 2003 Feb;38(1):51-6. https://doi.org/10.1034/i.1600-0765.2003.01636.x

23. Xiong J, Gronthos S, Bartold PM. Role of the epithelial cell rests of Malassez in the development, maintenance and regeneration of periodontal ligament tissues. Periodontol 2000. 2013 Oct;63(1):217-33. https://doi.org/10.1111/prd.12023 PMID:23931062
24. Stewart C. Timing of pulp extirpation for replanted avulsed teeth. Evid Based Dent. 2009;10(3):72. https://doi.org/10.1038/sj.ebd.6400664PMID:19820736

25. Panzarini SR, Gulinelli JL, Saito CT, Poi WR, Sonoda CK, Oliveira JA et al. Short-term vs long-term calcium hydroxide therapy after immediate tooth replantation: a histomorphometric study in monkey's teeth. Dent Traumatol. 2012 Jun;28(3):226-32. https://doi.org/10.1111/i.1600-9657.2011.01071.x PMID:22051142

26. Holland R, Soares IJ, Soares IM. Influence of irrigation and intracanal dressing on the healing process of dogs' teeth with apical periodontitis. Endod Dent Traumatol. 1992 Dec;8(6):223-9. https://doi.org/10.1111/j.1600-9657.1992.tb00248.x P

27. Safavi KE, Nichols FC. Effect of calcium hydroxide on bacterial lipopolysaccharide. J Endod. 1993 Feb;19(2):76-8. https://doi.org/10.1016/S0099-2399(06)81199-4

28. Andreasen JO, Borum MK, Jacobsen HL, Andreasen FM. Replantation of 400 avulsed permanent incisors. 2. Factors related to pulpal healing. Endod Dent Traumatol. 1995 Apr;11(2):59-68. https://doi.org/10.1111/j.1600-9657.1995.tb00462.x 